\title{
Evaluation of Flood Vulnerability of Typical Regions at Dongting Lake Area in China Based on Multi-source Information Digging and Fusion
}

Dehua Mao, Jinli Wang, Xiaohong Fu, Jinhui Li

College of Resources and Environmental Science, Hunan Normal University, Changsha 410081, China

\section{基于多源信息挖掘与融合的洞庭湖区典型区洪灾脆弱 性评估}

毛德华, 王金丽, 扶小红, 李锦慧

湖南师范大学资源与环境科学学院, 长沙 410081 , 中国

\begin{abstract}
The flood vulnerability comprehensive evaluation model was established through interpreting the remote sensing image data in 1987, 1998 and 2008 by means of ENVI4.8 and GIS, the collection and analysis to the historical disaster maps and statistical yearbook data of the flood disaster of Dongting Lake area in Hunan Province of China. With the method of analytic hierarchy process ( AHP) and the percentile to determine the vulnerability parameters of hazard-affected bodies, the influence of land use/cover change on flood vulnerability was studied. The flood vulnerability of typical region of Dongting Lake area was evaluated by means of the flood vulnerability comprehensive evaluation model. The research results show that the vulnerability parameters of hazard-affected bodies is different reflected that the different land use types have different influences on flood vulnerability; The flood vulnerability degree shows obvious spatial distribution ie. the hinterland area in the Dongting Lake area is sensitive to the flood hazard.
\end{abstract}

Keywords Land use/cover change; Flood vulnerability; multi-source information digging and fusion ; Dongting Lake area

摘要

运用 ENVI4.8 和 GIS 软件对 1987 年、1998 年和 2008
年三期遥感影像提取土地利用数据, 结合收集与分析 统计年鉴灾情、历史灾害图件等辅助资料, 以各类土 地作为承灾体, 利用层次分析法和百分数位法定量确 定承灾体脆弱性参数, 构建了洞庭湖区洪灾脆弱性综 合评估模型, 研究了土地利用与覆盖变化对洪灾脆弱 性的影响, 对洞庭湖区典型区域的洪灾脆弱性进行评 估分析, 结果表明: 各类承灾体的脆弱性参数不同, 反映出不同土地利用类型对洪灾脆弱性有不同的影 响; 1987-2008 年洪灾脆弱性值呈现不断增大的趋势 且具有一定的空间规律, 腹地区易受洪灾影响。

关键词: 土地利用/覆盖变化; 洪灾脆弱性; 多源信 息挖掘与融合; 洞庭湖区

\section{Introduction}

Flood disaster is an abrupt, high frequency, serious natural disasters, and caused huge losses in China every year. In recent years, vulnerability assessment has become hot research topic in the disaster science with the increasing frequency of flood disasters[1]. Dongting Lake is the second freshwater lake in China. Dongting Lake area has advantageous natural resources and is an important economic status in Hunan Province and in the China, yet is affected by the frequent flood hazard. In the past, the research on flood disaster in Dongting Lake area is of abundant contents [2-8], including the characteristics of flood disasters, the causing mechanism and control measures, vulnerability research. But flood don't cause the flood disaster certainly that is concerned with vulnerability of hazard-affected bodies. 


\section{Risk Analysis and Crisis Response in Big Data Era (RAC-16)}

Moreover, there are differences in the damage degree of different hazard-affected bodies for the same intensity flood, on the other hand, the damage degree of different intensity floods is different for the same hazard-affected body, so research on flood disaster must contain hazard-affected bodies including human beings[9]. Pang $\mathrm{X}$ analyzes the changes of the affected population in urban flood and identifies the function relationship between the hazard (rainstorm) and disaster-bearing body (population), which is called vulnerability curve of population in flood disaster[10]. Zhao $\mathrm{S}$ et al constructed the vulnerability regress model between crop's flood-effected area and average daily rainfall in a storm [11].

Taking the hazard-affected body as the object of study, flood vulnerability refers to the degree of loss for different hazard-affected bodies under certain social and economic conditions[9]. With the development of RS and GIS technique that are used to dig and fuse the multi-source data, multi-time phase data and multi-scale data, flood vulnerability research has been developed from concept analysis, concept connotation analysis and measurement index system to construct the vulnerability quantitative evaluation and the division mapping[7]. The most important function of human activities on the terrestrial system is the change of land use and land $\operatorname{cove}^{\mathrm{r}}[12]$. This paper studied the influence of land use/cover change on flood vulnerability by means of land use data in 1987, 1998 and 2008 that was extracted from three year remote sensing images in the Dongting Lake area. The Dongting Lake flood vulnerability comprehensive evaluation model was established taking land use types as hazard-affected body so as to evaluate the flood vulnerability of typical regions in Dongting Lake area .

\section{Overview of study region and data source}

Dongting Lake is situated in the north of Hunan Province and the middle reaches of the Yangtze Rive, and is of $2625 \mathrm{~km}^{2}$ water area. It is the second freshwater lake in China. Dongting Lake area includes the water area and the surrounding alluvial plain and hilly area. It belong to the subtropical moist climate, hot and rainy in summer, cold and dry in winter. Combination with literature and data of the remote sensing image, this paper selects the study region is the Dongting Lake area of Hunan Province which total area is $25761.66 \mathrm{~km}^{2}$ ( remote sensing image interpretation data), including the most of county and towns in the Yueyang City, Yiyang City, Changde City(Figure 1).

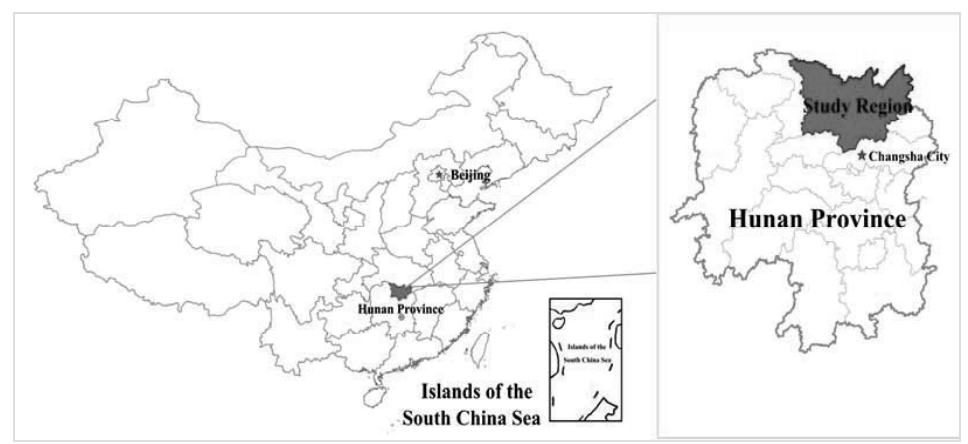

Figure 1 Schematic diagram of study area

With the development of RS and GIS technique that are used to dig and fuse of multi-source data, multi-time phase data and multi-scale data, the mapping and dynamic change monitoring are more systematic, objective, rapid and accurate[13]. In this paper, the remote sensing data come from 4 views of TM LandSat4-5 images, the track number is $123 / 39$, $123 / 40,124 / 39$ and $124 / 40$, resolution is $30 * 30 \mathrm{~m}$ 
Risk Analysis and Crisis Response in Big Data Era (RAC-16)

( Table 1 ) and cloudless cover image through the radiation correction and geometric correction, good image quality. In addition, a large number of other auxiliary datas were collected, including 1:50000 vector topographic map, administrative division map of YiYang City, YueYang City and ChangDe City, vector boundary map of the whole country and Hunan Province, statistical yearbook in 1987, 1998, 2008, social and economic data and Hunan province disaster statistical data, et al.

Table 1 Remote-sensing images for land use detection in Dongting Lake area

\begin{tabular}{ccccccc}
\hline \multirow{2}{*}{ Path/Ro } & \multicolumn{3}{c}{1987} & \multicolumn{3}{c}{1998} \\
w & Date & Senor & /Date & Senor & Date & Senor \\
\cline { 2 - 7 } $123 / 39$ & $10 / 09 / 1987$ & TM & $18 / 07 / 1998$ & TM & $16 / 07 / 2008$ & TM \\
$123 / 40$ & $25 / 08 / 1987$ & TM & $18 / 07 / 1998$ & TM & $16 / 07 / 2008$ & TM \\
$124 / 39$ & $03 / 07 / 1987$ & TM & $25 / 11 / 1998$ & TM & $16 / 07 / 2008$ & TM \\
$124 / 40$ & $03 / 07 / 1987$ & TM & $25 / 11 / 1998$ & TM & $16 / 07 / 2008$ & TM \\
\hline
\end{tabular}

3 Flood vulnerability evaluation model

values of flood disaster vulnerability.

\subsection{Theoretical basis}

Flood vulnerability refers to the degree of loss for different hazard-affected body under certain social and economic conditions, which is a standard of measurement and a predictive value[14-15]. Flood vulnerability evaluation should take into account the two problems: one is to consider the natural attributes from environment of developing geological hazards and disaster-causing factor, the two is the social and economic attributes of disaster bearing body. So flood vulnerability evaluation should include two aspects: flood risk and vulnerability of disaster bearing body[7].

The flood risk is mainly consider natural factors of flood disaster. Dongting Lake area hot and rainy in summer, precipitation concentration and inter-annual change is larger. The terrain is saucer basin, peripheral high, middle low. Sediment deposition leads to reduced storage capacity, easy to flooding. Taking into account the influence of land use/cover change on flood vulnerability and evaluate the typical area of Dongting Lake area. The land use and vulnerability are connected by the loss value of per unit area. Combined with historical statistics and land use type datas, using the method of analytic hierarchy process (AHP) and the percentile to calculate the loss value of per unit area. And then get the economic and population vulnerability parameters of flood disaster in Dongting Lake area[16] Economic and population vulnerability parameters reflect the impact of different land types, and finally all kinds of land vulnerability parameters are the weight

\subsection{Establish comprehensive evaluation mode} 3.2.1 Vulnerability classification system of disaster bearing body in Dongting Lake area

Using ENVI4.8 to get the land use/cover change datas by interpreting remote sensing image of 1987 , 1998 and 2008 in Dongting Lake area (Table 2). According to datas in the table show that the change of land use/cover occurred in different degrees from 1998 to 2008. The change of farmland area is the largest, following is the construction land, unused land and forest land; The change of grassland area and water area is small; And the area of farmland, grassland and unused land decreased, while the construction land, forest land and water area increased. According the statistical yearbook and historical datas to get the loss value of flood disaster (Table 3)[17]. Table 3 shows that the direct economic losses caused by flood disaster increasing and the countryside is more prominent, the damage area first increased after decreased, but the disaster area is increasing, since the 90 s of the 20th century.

In this paper, the vulnerability of disaster bearing body mainly includes two aspects: economic vulnerability and population vulnerability, and the loss value of flood disaster are based on them. Economic losses including economic losses of all kinds of land use types. Population losses including the damage population, the death toll, the missing population, the injured population, etc. The classification of disaster vulnerability in Dongting Lake area (Table 4)[18-21]. 
Risk Analysis and Crisis Response in Big Data Era (RAC-16)

Table 2 Land use / cover change statistics of the Dongting Lake area

\begin{tabular}{|c|c|c|c|c|c|c|}
\hline & 1987 & 1998 & $1987-1998$ & 2008 & $1998-2008$ & 1987-2008 \\
\hline $\begin{array}{l}\text { Land } \\
\text { type }\end{array}$ & $\begin{array}{c}\text { Area } \\
\left(\mathrm{km}^{2}\right)\end{array}$ & $\begin{array}{c}\text { Area } \\
\left(\mathrm{km}^{2}\right)\end{array}$ & $\begin{array}{c}\text { Increase and } \\
\text { decrease of area } \\
\left(\mathrm{km}^{2}\right)\end{array}$ & $\begin{array}{l}\text { Area } \\
\left(\mathrm{km}^{2}\right)\end{array}$ & $\begin{array}{l}\text { Increase and } \\
\text { decrease of } \\
\text { area }\end{array}$ & $\begin{array}{c}\text { Increase and } \\
\text { decrease of area } \\
\left(\mathrm{km}^{2}\right)\end{array}$ \\
\hline Farmland & 13514.3 & 14389.9 & 875.65 & 11756.6 & -2633.38 & -1757.72 \\
\hline Forestland & 5752.58 & 5314.50 & -438.08 & 6298.73 & 984.23 & 546.15 \\
\hline Grassland & 28.34 & 23.19 & -5.15 & 25.76 & 2.58 & -2.58 \\
\hline Water area & 2898.19 & 2623.89 & -274.30 & 2964.14 & 340.25 & 65.95 \\
\hline Construction & 742.83 & 955.76 & 212.93 & 2377.80 & 1422.04 & 1634.97 \\
\hline Unused land & 2825.41 & 2454.36 & -371.05 & 2338.64 & -115.72 & -486.77 \\
\hline Gross area & 25761.6 & 25761.6 & 0.00 & 25761.6 & 0.01 & 0.00 \\
\hline
\end{tabular}

Table 3 The severe flood disaster statistics in Dongting Lake area between 1991 to 2000

\begin{tabular}{|c|c|c|c|c|c|c|c|c|}
\hline \multirow[t]{2}{*}{$\begin{array}{c}\text { Yea } \\
\mathrm{r}\end{array}$} & \multirow{2}{*}{$\begin{array}{l}\text { Highest } \\
\text { water } \\
\text { level } / \mathrm{m}\end{array}$} & \multirow{2}{*}{$\begin{array}{c}\text { Damage } \\
\text { area } / 10^{5} \mathrm{~h} \\
\mathrm{a}\end{array}$} & \multirow{2}{*}{$\begin{array}{c}\text { Disaster } \\
\text { area } / 10^{5} \mathrm{~h} \\
\mathrm{a}\end{array}$} & \multicolumn{3}{|c|}{$\begin{array}{c}\text { Direct economic losses } \\
\left(/ 10^{8} \mathrm{RMB}\right)\end{array}$} & \multirow{2}{*}{$\begin{array}{c}\text { Damage } \\
\text { population/1 } \\
0^{8}\end{array}$} & \multirow{2}{*}{$\begin{array}{c}\text { Death } \\
\text { toll }\end{array}$} \\
\hline & & & & Town & $\begin{array}{l}\text { Countrysid } \\
\mathrm{e}\end{array}$ & Sum & & \\
\hline 1991 & 33.52 & 1.741 & 0.962 & 3.06 & 5.36 & 8.42 & 2.8732 & 52 \\
\hline 1993 & 33.04 & 3.15 & 1.442 & 3.94 & 7.90 & 11.84 & 4.3635 & 48 \\
\hline 1995 & 33.68 & 4.282 & 2.81 & 17.95 & 30.61 & 48.56 & 5.9911 & 92 \\
\hline 1996 & 35.31 & 4.78 & 2.524 & 66.20 & 85.94 & 152.14 & 6.7244 & 170 \\
\hline 1998 & 35.94 & 3.858 & 2.876 & 36.96 & 51.85 & 88.81 & 7.573 & 184 \\
\hline 1999 & 35.68 & 1.924 & 1.173 & 11.00 & 4.60 & 15.60 & 2.359 & - \\
\hline Sum & - & 19.735 & 11.787 & 139.11 & 186.26 & 325.37 & 29.8842 & 483 \\
\hline
\end{tabular}

Table 4 The classification of disaster vulnerability

\begin{tabular}{|c|c|c|c|}
\hline $\begin{array}{l}\text { Land use } \\
\text { types }\end{array}$ & $\begin{array}{l}\text { Classification of } \\
\text { economic losses }\end{array}$ & Classification of disaster losses & $\begin{array}{c}\text { Vulnerability of } \\
\text { disaster bearing } \\
\text { body }\end{array}$ \\
\hline Farmland & Agricultural e $1^{*}$ & $\begin{array}{l}\text { The damage area include cotton, rice, peanut, } \\
\text { corn and other crops. }\end{array}$ & Farmland \\
\hline Forestland & Forestry e 1 & The damage area of tree. & Forest land \\
\hline Grassland & Animal husbandry e 1 & $\begin{array}{l}\text { The damage area and economic losses of } \\
\text { grassland }\end{array}$ & Grassland \\
\hline Water area & Water area e 1 & $\begin{array}{l}\text { Affected area of fishery, the length of the dam } \\
\text { destroyed, wreck quantity,ect. }\end{array}$ & Water area \\
\hline Construction & Rural settlement e 1 & $\begin{array}{l}\text { Number of dead poultry, collapsed houses in } \\
\text { rural, etc. }\end{array}$ & Construction \\
\hline land & Urban land e 1 & $\begin{array}{l}\text { Collapsed houses in urban, the length of the } \\
\text { railway, highway destroyed,ecr. }\end{array}$ & land \\
\hline Unused land & Unused land e 1 & The damage area of tidal flat and bare land. & Unused land \\
\hline
\end{tabular}

*e l= economic losses

3.2.2 Determine the parameters vulnerability of disaster bearing body

(1) The comparison matrix of losses value

Through remote sensing images to get the area of disaster-bearing bodies, with the historical materials during 1978-2008 were used to investigate the loss value per hectare of flood disaster in Dongting Lake area(Table 5).

Then comparing the economic loss value of different disaster bearing bodies, we can construct the economic vulnerability comparison matrix of the flood disaster in 2008, 1998 and 1987, respectively(Table6-8). 
Risk Analysis and Crisis Response in Big Data Era (RAC-16)

Table 5 The economic loss value per hectare of flood disaster in Dongting Lake area (Ten thousand $\mathrm{RMB} / \mathrm{km}^{2}$ )

\begin{tabular}{ccccccc}
\hline Year & Farmland & Forestland & Water area & Construction land & Unused land & Grassland \\
\hline 1987 & 4.831 & 0.936 & 1.353 & 2.070 & 0.272 & 0.003 \\
1998 & 157.111 & 67.220 & 80.144 & 471.284 & 4.567 & 0.484 \\
2008 & 3.396 & 0.970 & 1.093 & 2.107 & 0.303 & 0.004 \\
\hline
\end{tabular}

Table 6 The comparison matrix of flood disaster vulnerability in 1987 in Dongting Lake area

\begin{tabular}{ccccccc}
\hline Disaster bearing body & Farmlan & Forestland & Water area & Construction land & Unused land & Grassland \\
\hline Farmland & 1.000 & 5.163 & 3.570 & 2.333 & 17.734 & 1778.468 \\
Forestland & 0.194 & 1.000 & 0.691 & 0.452 & 3.435 & 344.434 \\
Water area & 0.280 & 1.446 & 1.000 & 1.530 & 0.201 & 0.002 \\
Construction land & 0.429 & 2.213 & 1.530 & 1.000 & 7.600 & 762.210 \\
Unused land & 0.056 & 0.291 & 0.201 & 0.132 & 1.000 & 100.286 \\
Grassland & 0.001 & 0.003 & 0.002 & 0.001 & 0.010 & 1.000 \\
\hline
\end{tabular}

Table 7 The comparison matrix of flood disaster vulnerability in 1998 in Dongting Lake area

\begin{tabular}{|c|c|c|c|c|c|c|}
\hline Disaster bearing body & Farmland & Forestland & Water area & Construction land & Unused land & $\underset{d}{\text { Grasslan }}$ \\
\hline Farmland & 1.000 & 2.337 & 1.960 & 0.333 & 34.398 & 324.619 \\
\hline Forestland & 0.428 & 1.000 & 0.839 & 0.143 & 14.717 & 138.889 \\
\hline Water area & 0.510 & 1.192 & 1.000 & 5.880 & 0.057 & 0.006 \\
\hline Construction land & 3.000 & 7.011 & 5.880 & 1.000 & 103.183 & 973.760 \\
\hline Unused land & 0.029 & 0.068 & 0.057 & 0.010 & 1.000 & 9.437 \\
\hline Grassland & 0.003 & 0.007 & 0.006 & 0.001 & 0.106 & 1.000 \\
\hline
\end{tabular}

Table 8 The comparison matrix of flood disaster vulnerability in 2008 in Dongting Lake area

\begin{tabular}{ccccccc}
\hline Disaster bearing body & Farmland & Forestland & Eater area & Construction land & Unused land & Grassland \\
\hline Farmland & 1.000 & 3.500 & 3.109 & 1.612 & 11.212 & 949.946 \\
Forestland & 0.286 & 1.000 & 0.888 & 0.461 & 3.204 & 271.425 \\
Water area & 0.322 & 1.126 & 1.000 & 1.929 & 0.277 & 0.003 \\
Construction land & 0.620 & 2.171 & 1.929 & 1.000 & 6.956 & 589.368 \\
Unused land & 0.089 & 0.312 & 0.277 & 0.144 & 1.000 & 84.725 \\
Grassland & 0.001 & 0.004 & 0.003 & 0.002 & 0.012 & 1.000 \\
\hline
\end{tabular}

(2) Determining the scaling value and constructing the judgement matrix of flood disaster vulnerability

The scaling value represents the vulnerability of the two kinds of disaster bearing body. The greater values, the greater differences between the two types of disaster bearing body. Using the percentile method to select more than 1 elements from the comparison matrix of flood disaster vulnerability, and calculate each element percentile. From the order of the large to small to give 10 to 1 in turn. According to the scaling value obtained the judgment matrix of flood disaster vulnerability in 1987, 1998, 2008. (Table9-11).

(3) Economic and population vulnerability parameters

The consistency test results show that the economic vulnerability judgment matrix satisfies the consistency requirement. Analyzing the eigenvalues and eigenvectors of economic vulnerability jugement matrix in Dongting Lake area. The biggest eigenvector is the economic vulnerability parameters of different disaster bearing bodies and also is the influence weight of different land use types on economic vulnerability. 
Risk Analysis and Crisis Response in Big Data Era (RAC-16)

Table 9 The jugement matrix of flood disaster vulnerability in 1987 in Dongting Lake area

\begin{tabular}{ccccccc}
\hline Disaster bearing body & Farmland & Forestland & Water area & Construction land & Unused land & Grassland \\
\hline Farmland & 1.000 & 5.000 & 4.000 & 3.000 & 7.000 & 10.000 \\
Forestland & 0.200 & 1.000 & 1.000 & 0.500 & 4.000 & 8.000 \\
Water area & 0.250 & 1.000 & 1.000 & 0.500 & 5.000 & 9.000 \\
Construction land & 0.333 & 2.000 & 2.000 & 1.000 & 6.000 & 9.000 \\
Unused land & 0.143 & 0.250 & 0.200 & 0.167 & 1.000 & 7.000 \\
Grassland & 0.100 & 0.125 & 0.111 & 0.111 & 0.143 & 1.000 \\
\hline
\end{tabular}

Table 10 The jugement matrix of flood disaster vulnerability in 1998 in Dongting Lake area

\begin{tabular}{ccccccc}
\hline Disaster bearing body & Farmland & Forestland & Water area & Construction land & Unused land & Grassland \\
\hline Farmland & 1.000 & 2.000 & 2.000 & 0.333 & 7.000 & 9.000 \\
Forestland & 0.500 & 1.000 & 1.000 & 0.250 & 4.000 & 8.000 \\
Water area & 0.500 & 1.000 & 1.000 & 0.250 & 5.000 & 8.000 \\
Construction land & 3.000 & 4.000 & 4.000 & 1.000 & 6.000 & 10.000 \\
Unused land & 0.143 & 0.250 & 0.200 & 0.167 & 1.000 & 5.000 \\
Grassland & 0.111 & 0.125 & 0.125 & 0.100 & 0.200 & 1.000 \\
\hline
\end{tabular}

Table 11 The jugement matrix of flood disaster vulnerability in 2008 in Dongting Lake area

\begin{tabular}{ccccccc}
\hline Disaster bearing body & Farmland & Forestland & Water area & Construction land & Unused land & Grassland \\
\hline Farmland & 1.000 & 5.000 & 4.000 & 2.000 & 7.000 & 10.000 \\
Forestland & 0.200 & 1.000 & 1.000 & 0.500 & 4.000 & 8.000 \\
Water area & 0.250 & 1.000 & 1.000 & 0.500 & 5.000 & 9.000 \\
Construction land & 0.500 & 2.000 & 2.000 & 1.000 & 6.000 & 9.000 \\
Unused land & 0.143 & 0.250 & 0.200 & 0.167 & 1.000 & 7.000 \\
Grassland & 0.100 & 0.125 & 0.111 & 0.111 & 0.143 & 1.000 \\
\hline
\end{tabular}

From table 12 the economic vulnerability land and farmland are easy to cause economic loss in parameters in Dongting Lake area is farmland 0.3599, forestland 0.1348 , water area 0.1453 , construction land used 0.2928 , unused land 0.0485 , grassland 0.0188 . The economic vulnerability parameters are in the order of the farmland $>$ water area $>$ forestland $>$ unused land $>$ grassland. The construction land and farmland parameter value is biger, indicating that construction Dongting Lake area; Unused land and grassland parameter is smaller, the flood disaster was less affected.

The population vulnerability parameters are measured by the disaster-affected population in different disaster bearing bodies(Table 13).

Table 12 The economic vulnerability parameters of flood disaster in Dongting Lake area

\begin{tabular}{ccccccc}
\hline Year & Farmland & Forestland & Water area & Construction land & Unused land & Grassland \\
\hline 1987 & 0.4356 & 0.1316 & 0.1446 & 0.2212 & 0.0488 & 0.0182 \\
1998 & 0.2315 & 0.1394 & 0.1447 & 0.4173 & 0.0471 & 0.0200 \\
2008 & 0.4125 & 0.1334 & 0.1465 & 0.2398 & 0.0495 & 0.0184 \\
Mean & 0.3599 & 0.1348 & 0.1453 & 0.2928 & 0.0485 & 0.0188 \\
\hline
\end{tabular}

Table 13 The population vulnerability parameters of flood disaster in Dongting Lake area

\begin{tabular}{ccccccc}
\hline Land use type & Farmland & Forestland & Water area & Construction land & Unused land & Grassland \\
\hline Flood disaster & 0.069 & 0.023 & 0.048 & 0.943 & 0.012 & 0.008 \\
\hline
\end{tabular}


Risk Analysis and Crisis Response in Big Data Era (RAC-16)

From the table shows that the high population vulnerability of flood disaster in Dongting Lake area is mainly the construction land, including the rural residential land and urban land use; The moderate population vulnerability are farmland and water area, which are less than the construction land; The low population vulnerability area including unused land and grassland is small, especially the grassland has little impact on the vulnerability of flood disaster.

3.2.3 Establish the flood vulnerability comprehensive evaluation model

This paper mainly considers effects of different land types on the flood vulnerability from the economy and population, through analysis and determination of the economic and population vulnerability parameters and then establish the flood vulnerability comprehensive evaluation model are as follows:

$$
T=\sum_{i=1}^{n}\left(\alpha_{i}+\beta_{i}\right) * \chi_{i}
$$

Formula(1), $T$ is vulnerability value, $\alpha_{i}$ and $\beta_{i}$ is economic and population vulnerability parameter values respectively of $i$ land use type, $\chi_{i}$ is the area of $i$ land use type. Thus the flood vulnerability comprehensive evaluation model of Dongting Lake area is follows:

$$
\begin{aligned}
& \mathrm{T}=0.4289 \chi_{1}+0.1878 \chi_{2}+0.1933 \chi_{3} \\
& +1.2358 \chi_{4}+0.0605 \chi_{5}+0.0268 \chi_{6}
\end{aligned}
$$

Formula (2), $\chi_{1}, \chi_{2}, \cdots, \chi_{6}$ respectively is the farmland area, the forestland area, the water area, the construction land area, the unused land area and the grassland area. The formula takes economic and population vulnerability parameter values as the weight of flood vulnerability, and reflects the influence degree of the change of land use types to the flood vulnerability.

\section{Evaluation of flood vulnerability of two typical regions at Dongting Lake area}

The flood vulnerability comprehensive evaluation model is applied in two typical regions respectively is Dingcheng District in Changde, located in the edge of Dongting Lake area , and Nanxian County in Yiyang, located in the hinterland of Dongting Lake area. The flood vulnerability in Dingcheng Distric and Nanxian County are analyzed according to land use datas from 2000, 2005, 2010 and planning datas from 2020. Comparative analysis of the purpose is to study the distinction and connection of the flood vulnerability between the hinterland and other areas, as well as towns. In the end of drawing the spatial distribution map of flood vulnerability, which can show the relative size of the vulnerability and provide the guidance for the flood disaster prevention and reduction.

\subsection{Analysis of flood vulnerability in Nanxian County and Dingcheng District}

Using the model to calculate the vulnerability values of 12 townships in Nanxian County ( Table 14 ) and 42 townships in Dingcheng District ( Table 15 ). According land use datas in 2000, 2005, 2010 and 2020 to draw the 2020 spatial distribution map of flood vulnerability in townships of Dingcheng District

Table 14 The vulnerability value of flood disaster in Nanxian County

\begin{tabular}{ccccc}
\hline & 2000 & 2005 & 2010 & 2020 \\
\hline Guangyao Town & 3081.80 & 3086.56 & 3101.10 & 3117.61 \\
Huage Town & 4757.94 & 4768.26 & 4751.15 & 4670.88 \\
Langba lake Town & 4610.79 & 4622.26 & 4662.87 & 4830.45 \\
Mahekou Town & 5121.45 & 5144.21 & 5230.51 & 5291.29 \\
Maocaojie Town & 4661.72 & 4647.68 & 4736.54 & 4928.42 \\
Mingshantou Town & 3071.39 & 3091.58 & 3120.31 & 3076.43 \\
Nanzhou Town & 4646.93 & 4747.34 & 5069.20 & 5278.33 \\
Qingshuzui Town & 3648.92 & 3655.27 & 3720.36 & 3815.51 \\
Sanxian lake Town & 4466.60 & 4478.74 & 4507.36 & 4627.99 \\
Wuzui Town & 3440.47 & 3458.02 & 3496.75 & 3597.57 \\
Wushenggong Town & 2377.93 & 2399.75 & 2430.46 & 2496.59 \\
Zhongyukou own & 4579.55 & 4591.85 & 4608.76 & 4654.52 \\
Sum & 48465.49 & 48691.54 & 49435.35 & 50385.59 \\
\hline
\end{tabular}


Risk Analysis and Crisis Response in Big Data Era (RAC-16)

Table 15 The vulnerability value of flood disaster in Dingcheng District

\begin{tabular}{|c|c|c|c|c|}
\hline & 2000 年 & 2005 年 & 2010 年 & 2020 年 \\
\hline Haozigang Town & 2237.23 & 2232.52 & 2231.79 & 2226.35 \\
\hline Heishanzui Town & 1652.33 & 1654.85 & 1657.79 & 1689.72 \\
\hline Huangzhuzhou Town & 1443.89 & 1441.42 & 1439.12 & 1441.77 \\
\hline Zhonghekou Town & 2820.53 & 2820.79 & 2824.77 & 2906.94 \\
\hline Shimeitang Town & 1872.20 & 1892.12 & 1912.62 & 1951.51 \\
\hline Niubitan Town & 3313.73 & 3178.02 & 3160.96 & 3152.62 \\
\hline Hangongdu Town & 4950.88 & 4950.67 & 4953.59 & 5030.47 \\
\hline Shigongqiao Town & 4201.44 & 4200.00 & 4207.11 & 4172.33 \\
\hline Zhendeqiao Town & 2046.33 & 2050.02 & 2065.44 & 2080.66 \\
\hline Zhoujiadian Town & 5314.98 & 5262.67 & 5307.52 & 5359.93 \\
\hline Baiheshan Town & 3756.66 & 3761.15 & 3820.08 & 3743.12 \\
\hline Dalongzhan Town & 1448.93 & 1424.81 & 1453.49 & 1474.25 \\
\hline Shuangqiaoping Town & 2487.31 & 2419.10 & 2398.70 & 2463.35 \\
\hline Changlinggang Town & 1530.04 & 1511.39 & 1525.58 & 1510.77 \\
\hline Guanxi Town & 2666.81 & 2682.16 & 2732.98 & 3026.06 \\
\hline Caijiagang Town & 2209.05 & 2212.03 & 2240.65 & 2238.33 \\
\hline Shibantan Town & 2376.50 & 2392.17 & 2442.84 & 2543.50 \\
\hline Leigongmiao Town & 2169.42 & 2124.94 & 2149.68 & 2190.59 \\
\hline Doumuhu Town & 2071.38 & 2127.08 & 2169.97 & 2321.91 \\
\hline Xujiaqiao Town & 2290.28 & 2282.76 & 2284.80 & 2276.43 \\
\hline Dingjiagang Town & 2177.79 & 2168.32 & 2176.24 & 2140.68 \\
\hline Caoping Town & 2916.97 & 2901.42 & 2922.47 & 2885.95 \\
\hline Shimenqiao Town & 4584.43 & 4551.21 & 4570.20 & 4617.87 \\
\hline Xiejiapu Town & 2558.96 & 2546.37 & 2556.46 & 2549.75 \\
\hline Huangtudian Town & 2749.37 & 2729.22 & 2762.74 & 2739.86 \\
\hline Qianjiaping Town & 2085.04 & 2069.68 & 2131.99 & 2137.20 \\
\hline Tangjiapu Town & 1847.09 & 1793.24 & 1854.13 & 1824.03 \\
\hline Cangshan Town & 1948.50 & 1943.03 & 2016.44 & 1993.48 \\
\hline Yaotianping Town & 2148.51 & 2134.22 & 2197.09 & 2216.36 \\
\hline Changmaoling Town & 2239.36 & 2223.82 & 2255.59 & 2240.77 \\
\hline Gangerkou Town & 2172.16 & 2158.93 & 2203.28 & 2212.28 \\
\hline Nijiangping Town & 2047.17 & 2019.65 & 2051.95 & 2031.39 \\
\hline Wuling Town & 2050.71 & 2080.76 & 2110.46 & 2545.35 \\
\hline Huayanxi Town & 880.62 & 878.66 & 882.77 & 879.28 \\
\hline Quzhi Town & 3783.45 & 3775.71 & 3798.25 & 3770.82 \\
\hline Sum & 89050.04 & 88594.93 & 87746.81 & 88830.30 \\
\hline
\end{tabular}

( Figure 2 ) and the 2020 spatial distribution map of flood vulnerability in townships of Nanxian County ( Figure 3 ).

\subsection{Result analysis}

Analysis of the flood vulnerability in 2020, 2005, 2010 and 2000, results show that the difference and connection between two typical regions (Table 16). Through the analysis of the vulnerability distribution rule in Dongting Lake area are as follows:

(1) Speaking in general, the vulnerability of Nanxian County more than Dingcheng District according to the value of the vulnerability in 2000, 2005, 2010 and 2020. 
Risk Analysis and Crisis Response in Big Data Era (RAC-16)

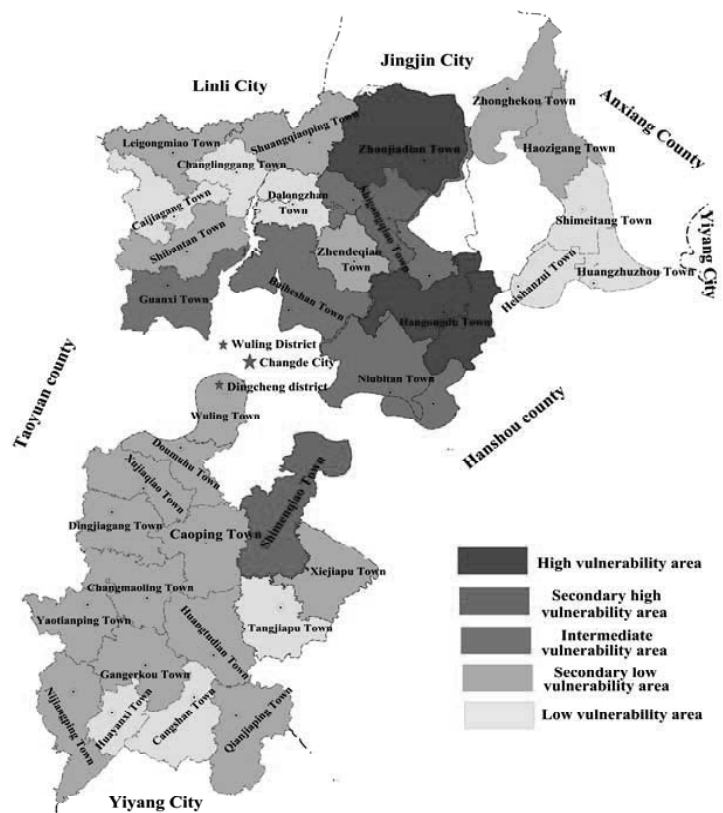

Figure 2 The distribution of flood vulnerability in townships of Dingcheng District

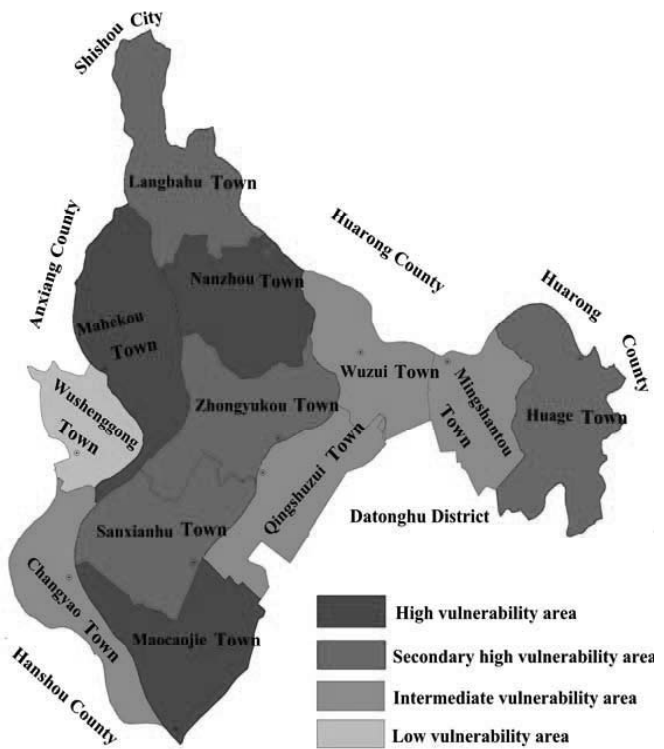

Figure 3 The distribution of flood vulnerability in townships of Nanxian County 
Risk Analysis and Crisis Response in Big Data Era (RAC-16)

Table 16 The analysis of flood vulnerability in Nanxian County and Dingcheng District

\begin{tabular}{|c|c|c|c|c|}
\hline & \multicolumn{2}{|c|}{ Nanxian County } & \multicolumn{2}{|c|}{ Dingcheng District } \\
\hline Climate & \multicolumn{2}{|c|}{$\begin{array}{l}\text { Subtropical climate transition to } \\
\text { monsoon moist climate }\end{array}$} & \multicolumn{2}{|c|}{$\begin{array}{l}\text { Continental climate is the main, } \\
\text { with the maritime climate }\end{array}$} \\
\hline Terrain & \multicolumn{2}{|c|}{$\begin{array}{l}\text { Plain terrain, from the west } \\
\text { slope to the southeast }\end{array}$} & \multicolumn{2}{|c|}{$\begin{array}{l}\text { Subdued topography is the main, both low } \\
\text { mountains and hills, southwest slope to } \\
\text { northeast }\end{array}$} \\
\hline $\begin{array}{l}\text { General } \\
\text { tendency }\end{array}$ & \multicolumn{2}{|c|}{$\begin{array}{l}\text { On the whole, the total value of flood } \\
\text { vulnerability in Nanxian County has } \\
\text { been increasing from } 2000 \text { to } 2020 \text {.. }\end{array}$} & \multicolumn{2}{|c|}{$\begin{array}{l}\text { In general show a trend of increasing, } \\
\text { particularly in 2000-2010 decreased, } \\
2010-2020 \text { increased, but less than } 2005\end{array}$} \\
\hline \multirow{5}{*}{$\begin{array}{l}\text { Individual } \\
\text { difference of } \\
\text { each } \\
\text { township } \\
\text { (Different } \\
\text { natural } \\
\text { resources } \\
\text { and location } \\
\text { difference } \\
\text { lead to } \\
\text { different } \\
\text { vulnerability } \\
\text { ) }\end{array}$} & $\begin{array}{c}\text { High } \\
\text { vulnerability } \\
\text { area, }(\geqq 5000)\end{array}$ & $\begin{array}{l}\text { Mahekoutown, } \\
\text { Maocaojie town, } \\
\text { Nanzhou town }\end{array}$ & $\begin{array}{c}\text { High } \\
\text { vulnerability } \\
\text { area, }(\geqq 5000)\end{array}$ & Zhoujiadian Town \\
\hline & $\begin{array}{l}\text { Secondary high } \\
\text { vulnerability } \\
\text { area } \\
(4000-5000)\end{array}$ & $\begin{array}{l}\text { Huage Town, } \\
\text { LangbahuTtown, } \\
\text { Sanxianhu Town, } \\
\text { Zhongyukou Town }\end{array}$ & $\begin{array}{l}\text { Secondary high } \\
\text { vulnerability } \\
\text { area } \\
(4000-5000)\end{array}$ & $\begin{array}{l}\text { Hangongdu Town, } \\
\text { Shigongqiao Town, } \\
\text { Shimenqiao Town }\end{array}$ \\
\hline & $\begin{array}{l}\text { Intermediate } \\
\text { vulnerability } \\
\text { area } \\
(3000-4000) \\
\end{array}$ & $\begin{array}{l}\text { Guangyao Town, } \\
\text { Mingshantou Town, } \\
\text { Qingshuzui Town, } \\
\text { Wuzui Town }\end{array}$ & $\begin{array}{l}\text { Intermediate } \\
\text { vulnerability } \\
\text { area } \\
(3000-4000) \\
\end{array}$ & $\begin{array}{l}\text { Niubitan Town, } \\
\text { Baiheshan Town, } \\
\text { Quzhi Town }\end{array}$ \\
\hline & \multirow[t]{2}{*}{$\begin{array}{c}\text { Low } \\
\text { vulnerability } \\
\text { area, } \\
(<3000)\end{array}$} & \multirow[t]{2}{*}{ Wushenggong Town } & $\begin{array}{l}\text { Secondary low } \\
\text { vulnerability } \\
\text { area } \\
(2000-3000)\end{array}$ & $\begin{array}{c}\text { Haozigang Town, } \\
\text { Zhonghekou Town, } \\
\text { Zhengdeqiao Town, } \\
\text { Shuangqiaoping Town, } \\
\text { Guanxi town, Caijiagang } \\
\text { town, Shibantan Town, } \\
\text { Leigongmiao Town, } \\
\text { Doumuhu Town, Xujiaqiao } \\
\text { Town, Dingjiagang Town, } \\
\text { Caoping town, Xiejiapu } \\
\text { Town, Huangtudian Town, } \\
\text { Qianjiaping Town }\end{array}$ \\
\hline & & & $\begin{array}{c}\text { low } \\
\text { vulnerability } \\
\text { area, } \\
(<2000)\end{array}$ & $\begin{array}{c}\text { Heishanju town, } \\
\text { Huangzhuzhou town, } \\
\text { Shimeitang town, } \\
\text { Dalongzhan town, } \\
\text { Changlinggang town, } \\
\text { Tangjiapu town, Cangshan } \\
\text { town, Huayanxi town }\end{array}$ \\
\hline $\begin{array}{l}\text { Planning } \\
\text { year } 2020\end{array}$ & \multicolumn{2}{|c|}{$\begin{array}{l}\text { The vulnerability of each township in } \\
2020 \text { were more than the previous } \\
\text { years, and showed a rising trend.The } \\
\text { largest change of the vulnerability and } \\
\text { the fastest growing is Nanzhou Town, } \\
\text { followed by Mahekou Town, } \\
\text { Sanxianhu Town, Maocaojie } \\
\text { Town, Wuzui Town. The vulnerability } \\
\text { of the predicted } 2020 \text { years in Huage } \\
\text { Town and Mingshantou Twno will be } \\
\text { reduced. }\end{array}$} & \multicolumn{2}{|c|}{$\begin{array}{l}\text { The vulnerability values of most towns more } \\
\text { than in 2010, which the most obvious is } \\
\text { Wuling Town, followed by Guanxi Town, } \\
\text { Zhonghe Town, Hangongdu Town, Shibantan } \\
\text { Town, Doumu Town. While Shigongqiao } \\
\text { Town, Haozigang Town, Dingjiagang } \\
\text { own,Caoping town,Huangtudian town, } \\
\text { Tangjiapu Town,Cangshan } \\
\text { Town,Changlinggang Town, Nijiangping Town } \\
\text { and Quzhi Town are reduction, other towns } \\
\text { almost no change. }\end{array}$} \\
\hline
\end{tabular}


Risk Analysis and Crisis Response in Big Data Era (RAC-16)

The level of vulnerability is closely related to the local social economy, and social and economic changes have resulted in the change of land use types. After compared and analyzed the change of land use between hinterland of plain (Nanxian County) and edge area (Dingcheng District), the results showed that the vulnerability of the hinterland area is large and the changing amplitude is large.

(2) From 2000 to 2020, the vulnerability of Nanxian County and Dingcheng District showed an increasing trend, however, the vulnerability of townships have differences; The vulnerability of each township has different changes, some are first increased and then decreased, others are decreased and then increased.

(3) Disaster prevention and reduction should focus on the hinterland area, take measures to reduce the vulnerability and optimize the structure of land use according to the level of vulnerability.

\section{Conclusion}

At present, the research on the vulnerability of flood disaster is relatively small, and the vulnerability assessment of the disaster bearing body is relatively backward. In order to better and more accurate assess the vulnerability of disaster bearing bodies, this paper through the collection and analysis to the historical materials of the flooding disaster in Dongting Lake area and using ENVI4.8, GIS to mine land use datas, with the method of analytic hierarchy process (AHP) and the percentile to determine the vulnerability parameters of disaster bearing bodies and study the influence of land use/cover change on flood vulnerability. Then according vulnerability parameters to establish the flood vulnerability comprehensive evaluation model in Dongting Lake area. Using the model of vulnerability to evaluate the typical area of Dongting Lake area and with parameters as the weight of the vulnerability of land types to draw the spatial distribution map of flood vulnerability, the results show:

(1) Based on remote sensing datas and historical materials, analysis of the impact of land use / cover change on the flood vulnerability, to achieve the objective and quantitative evaluation for flood vulnerability in Dongting Lake area.
(2) The vulnerability parameters of disaster bearing bodies are different, suggesting that the differences of impact of different land use types on flood vulnerability.

(3) Evaluate the flood vulnerability of typical area in Dongting Lake area find that the flood vulnerability present a certain spatial distribution rule, the hinterland area is vulnerable to floods and the vulnerability is the biggest.

\section{Acknowledgments}

This study was supported by the Key Research Project of Hunan Provincial Education Department(grant no.15A113), the Construct Program of the Key Discipline in Hunan Province of China(2011001) and the Key Research Project of Hunan Provincial Water Resources Department(grant no.

( [2015]13-22).

\section{致谢}

本研究湖南省教育厅重点项目 (15A113)、湖南 省重点学科建设项目 (2011001) 和湖南省水利重大项 目（[2015]13-22) 资助。

\section{References}

[1] Zeng J. Zhu Z. Zhang J. (2010). Population Vulnerability Assessment on County-scale Geohazards Based on High Spatial Resolution Satellite Imagery: A Case Study of Luogang District, Guangzhou. Tropical Geography 30(4):386-391.

[2] Mao D. (1998). Analysis of flood characteristics in Dongting Lake Region from to 1996. Journal of Lake Science 10(2):85-91.

[3] Zeng Q. Guo Y. (2003). Characteristics of the flood disasters and its causes in Dongting Lake area. Journal of Geological Hazards and Environment Preservation 14(3):55-66.

[4] Mao D. Xia J. (2005). Causing mechanism analysis of flood and waterlogged disaster in Dongting Lake Region. Journal of Wuhan University (Natural Science Edition) 51(2):199-203.

[5] Liu S. Zhao X. (2003). Causes of flooding and 


\section{Risk Analysis and Crisis Response in Big Data Era (RAC-16)}

waterlogging disasters in the Dongting Lake region and some countermeasures. Chinese Journal of Ecology 22 (6):147-151.

[6] Hu W. (2009). Strategic control of the flood disaster based on the geologic history in the area of the Dongting Lake. China University of Geosciences.

[7] Mao D. Zhou J. Li J. (2010). Application of projection pursuit method based on genetic algorithm to vulnerability evaluation of flood disasters. Journal of Glaciology and Geocryology 32(10):389-396

[8] Mao D. (2001). Comprehensive assessment and analysis on the risk degree of flood-waterlogging in Dongting Lake region. Journal of Natural Disasters 10(4):104-107.

[9] Gao J. Pan Y. Liu H. (2004). Assessment on regional vulnerability to flood. Research of Environmental Sciences 17(6):30-34

[10] Pang X. (2013). Dynamic vulnerability analysis of population for flood disaster in urban area. Journal of Risk Analysis and Crisis Response, 3(4): 166-174.

[11] Zhao S, Zhang Q.(2012). Risk assessment of crops induced by flood in the three northeastern provinces of China on small space-and-time scales. Journal of Risk Analysis and Crisis Response, 2(3):201-208.

[12] Eric F. B L Turner. Helmut J. Geist. (2001). The cause of land-use and land-cover change: moving beyond the myths. Global Environmental Change.

[13] Liu J. (1997). Study on national resources \& environment survey and dynamic monitoring using Remote Sensing. Journal of Remote
Sensing 1(3):225-230

[14] Chen C. (2009). Study on vulnerability assessment of geo-hazards in southwest mountainous Towns - Wenchuan county town as an example. Chengdu University Of Technology.

[15] Ding Z. (2013). A Study on the technology and method of flood and waetrlogging disaster loss assessment based on RS and GIS. Journal of China Institute of Water Resources and Hydropower.

[16] Song Y. (2013). Method for vulnerability parameters calibration of disaster bearing body assessment model and the practice. Nanjing University of Information Science \& Technology.

[17] Liu Z. (2004). Study on the flood disaster and control measures in the Dongting Lake region. Wuhan University.

[18] Qiu X. Zhu Y. Zeng Y. (2013). A Quantitative method for vulnerability parameters calibration of disaster bearing body in meteorological disaster risk assessment model-Case study of drought and flood in Weifang. Science Technology and Engineering 13(22):16-25.

[19] Fan Y. Luo Y. Chen Q. (2001). Research on indexes system about regional vulnerability assessment. Journal of Geoscience 15(1):69-116.

[20] Guo Y. Zhu F. (2010). Construction of framework of evaluation index system of social vulnerability to natural disasters. Journal of Catastrophology 25(4):69-71.

[21] Fan Y. Luo Y. Chen Q. (2001). Establishment of weight about vulnerability indexes of hazard bearing body. Journal of Catastrophology 16(1):85-87. 